Short Report

\title{
3-year Follow-up Results of Abant Izzet Baysal University Training and Research Hospital Patients with Pulmonary Hypertension
}

\author{
Aslı KURTAR MANSIROĞLU ${ }^{1}$
}

${ }^{1}$ Abant İzzet Baysal University Training and Research Hospital, Bolu, Turkey

Turk J Int Med 2021;3(Supplement 1):S10-S13

DOI: $\underline{10.46310 / \text { tjim.866344 }}$

Keywords: Pulmonary hypertension, follow-up, Right heart catheterization

Pulmonary hypertension $(\mathrm{PH})$ is defined as the mean pulmonary artery pressure (mPAB) measured by right heart catheterization (RHC) 25 $\mathrm{mmHg}$ or higher at rest. Different hemodynamic $\mathrm{PH}$ definitions were made according to the combinations of pulmonary artery pressure measured by right heart catheterization, pulmonary artery end pressure (PCWP), cardiac output (CO), diastolic pressure gradient, and pulmonary vascular resistance (PVR). ${ }^{1}$ The differential diagnosis of $\mathrm{PH}$ is at least as important as its treatment, as it is a condition that can cause many diseases. Symptoms and signs include shortness of breath, lightheadedness, syncope, tiredness, chest pain, swelling of the legs, poor appetite, chest pain, right-sided abdominal pain, palpitations, cyanosis and rarely non-productive cough, exercise-induced nausea, and vomiting. We herein present 3-year follow-up results of patients with $\mathrm{PH}$.

In symptomatic patients with suspected $\mathrm{PH}$, those with the possibility of $\mathrm{PH}$ echocardiographically were evaluated in our clinic with a multidisciplinary approach. Left heart diseases and lung diseases were excluded as a result of the evaluations of Chest Diseases, Internal medicine, and Rheumatology departments. RHC was performed in our clinic between January 2018 and January 2021 to confirm the diagnosis of group $1 \mathrm{PH}$ in 30 patients whose chronic thromboembolic $\mathrm{PH}$ (CTEPH) diagnosis was excluded by negative ventilationperfusion scintigraphy and/or pulmonary CT angiography. Considering the $\mathrm{PH}$ etiology of the patients; Eisenmenger syndrome due to congenital diseases in 2 patients; Group $4 \mathrm{PH}$ in 7 patients; Group $2 \mathrm{PH}$ in 3 patients; idiopathic $\mathrm{PH}$ diagnosis in 5 patients, and 5 patients were diagnosed with $\mathrm{PH}$ secondary to connective tissue diseases, and thus, pulmonary arterial hypertension (PAH)specific treatment was initiated in a total of 22 patients (Table 1). In our clinic, vasoreactivity test is performed with adenosine. There was no vasoreactivity response in any of the patients who underwent the vasoreactivity test.

$\mathrm{PAH}$ was followed-up before specific treatment

Received:January 22,2021;Accepted:March 3,2021; Published Online:March 6, 2021
Addressfor Correspondence:
Asli KURTARMANSIROGLU
Abant İzzet Baysal University Training and Research Hospital, Bolu, Turkey
E-mail:dr.aslikurtar@gmail.com


Table 1. Clinical classification of 22 patients with pulmonary hypertension

\begin{tabular}{ll}
\hline PH subtypes & Patient number \\
\hline Group 1 PAH & Idiopathic PAH $(\mathrm{n}=5)$ \\
& Connective tissue disease $(\mathrm{n}=5)$ \\
& Congenital heart disease $(\mathrm{n}=2)$ \\
Group 2 PH & PH due to left heart disease $(\mathrm{n}=3)$ \\
Group 4 PH (CTEPH and other & CTEPH $(\mathrm{n}=3)$ \\
pulmonary artery obstructions) & Operated due to CTEPH and residue PH $(\mathrm{n}=2)$ \\
& Operated due to hydatid cyst and residue PH $(\mathrm{n}=1)$ \\
& Arteritis $(\mathrm{n}=1)$ \\
\hline
\end{tabular}

PAH: pulmonary arterial hypertension, $\mathrm{PH}$ : pulmonary hypertension, CTEPH: chronic thromboembolic pulmonary hypertension.

was initiated because of isolated postcapillary $\mathrm{PH}$ or the average PAP $<25 \mathrm{mmHg}$ in 8 patients according to RHC findings. When the treatments received by the patients were examined, 5 patients were referred to as single $\mathrm{PH}$ specific therapy; 14 patients dual combination therapy; 3 patients received triple combination therapy (Table 2). Since there was no vasodilator response in patients who underwent vasoreactivity test during right heart catheterization, no patient was followed up with high-dose calcium channel blocker. During their follow-up, 9 of our patients were followed up in the NHYA 1, 10 in the NHYA 2, 1 in the NHYA 3 , and 2 in the NHYA 4 clinic, and one of these patients started subcutaneous prostanoid treatment in an external center; 1 patient in group
2 with precapillary and postcapillary PHT died in our hospital.

A diagnosis of $\mathrm{PH}$ requires clinical suspicion based on symptoms and physical examination. A series of examinations are required to determine the compliance of this suspicion with hemodynamic criteria, the etiology of the disease, and the functional and hemodynamic severity. These examinations should at least be interpreted by a multidisciplinary team of Cardiology, Rheumatology, Radiology, and Chest Diseases specialists. In our daily practice, it is necessary to raise awareness for this patient group, whose diagnosis is delayed, and the specialist referral centers should be determined and the referral chain should be operated.

Table 2. Pharmacological treatments given to patients

\begin{tabular}{lcccc}
\hline Treatment & $\begin{array}{c}\text { Patient } \\
\text { number }\end{array}$ & $\begin{array}{c}\text { Side } \\
\text { effect }\end{array}$ & $\begin{array}{c}\text { Combination } \\
\text { therapy }\end{array}$ & $\begin{array}{c}\text { Drug } \\
\text { monotherapy }\end{array}$ \\
\hline Endothelin receptor antagonists & & & & \\
Bosentan & 8 & 2 & 7 & 1 \\
Macitentan & 5 & - & 4 & 1 \\
Ambrisentan & 3 & - & 3 & - \\
Phosphodiesterase type 5 inhibitors & & & & - \\
Sildenafil & 9 & - & 9 & - \\
Tadalafil & 5 & - & 5 & 3 \\
Guanylate cyclase stimulators & & & & - \\
Riociguat & 7 & - & 4 & - \\
Prostacyclin analogues & & & & - \\
$\begin{array}{l}\text { Iliprost (inhaled) } \\
\text { Subkutan PG }\end{array}$ & 3 & 1 & 3 & - \\
IP receptor agonists & 1 & - & 1 & \\
Selexipag & & & & \\
\hline
\end{tabular}




\section{Conflict of Interests}

Authors declare that there are none.

\section{Acknowledgment}

This study has been presented in $17^{\text {th }}$ Uludag Internal Medicine National Winter Congress, $6^{\text {th }}$ Bursa Family Medicine Association National Congress, $11^{\text {th }}$ Uludag Internal Medicine Nursing Congress, 5-7 March 2021, Bursa, Turkey.

\section{References}

1. World Health Organization. WHO fact sheet on Galiè N, Humbert M, Vachiery JL, Gibbs S, Lang I, Torbicki A, Simonneau G, Peacock A, Vonk Noordegraaf
A, Beghetti M, Ghofrani A, Gomez Sanchez MA, Hansmann G, Klepetko W, Lancellotti P, Matucci M, McDonagh T, Pierard LA, Trindade PT, Zompatori M, Hoeper M; ESC Scientific Document Group. 2015 ESC/ERS Guidelines for the diagnosis and treatment of pulmonary hypertension: The Joint Task Force for the Diagnosis and Treatment of Pulmonary Hypertension of the European Society of Cardiology (ESC) and the European Respiratory Society (ERS): Endorsed by: Association for European Paediatric and Congenital Cardiology (AEPC), International Society for Heart and Lung Transplantation (ISHLT). Eur Heart J. 2016 Jan 1;37(1):67-119. doi: 10.1093/eurheartj/ehv317. Boucher BJ, Mannan N, Noonan K, Hales CN, Evans SJ. Glucose intolerance and impairment of insulin secretion in relation to vitamin D deficiency in east London Asians. Diabetologia. 1995 Oct;38(10):123945. doi: 10.1007/BF00422375. 